\title{
Small and Medium Scale Enterprises and Economic Growth in Nigeria: 1975-2012
}

\author{
Imoisi Anthony Ilegbinosa ${ }^{1} \&$ Ephraim Jumbo ${ }^{2}$ \\ ${ }^{1}$ College of Social \& Management Sciences, McPherson University, Ogun State, Nigeria \\ ${ }^{2}$ Treasury Department, Emohua Local Government Area, Rivers State, Nigeria \\ Correspondence: Imoisi Anthony Ilegbinosa, College of Social \& Management Sciences, McPherson University, \\ Seriki Sotayo, Km 96, Lagos-Ibadan Expressway, P.M.B. 2094, Abeokuta, Ogun State, Nigeria. E-mail: \\ mcanthonyby@yahoo.co.uk
}

Received: December 16, 2014

Accepted: January 13, 2015 Online Published: February 27, 2015

doi:10.5539/ijbm.v10n3p203

URL: http://dx.doi.org/10.5539/ijbm.v10n3p203

\begin{abstract}
This paper empirically examines Small and Medium Scale Enterprises and Nigeria's economic growth from 1970 - 2012. The benefits of SMEs to any economy are easily noticeable. These includes: creation of jobs, provide a vehicle for reducing income disparities, increase the output of goods and services produced in the economy etc. The main objective of this paper is to examine the impact of SMEs on economic growth in Nigeria. In order to achieve this objective, the study polled 84 SMEs for primary data collection as well as statistical records for years 1975-2012 as secondary data. The ordinary least square, co-integration and error correction model was used to estimate the data collected during the period of this study. The variables used include Gross Domestic Product as the dependent variable and Finance Available to Small and Medium Enterprises, Interest rate and Inflation rate as the independent variables. Our result showed that Finance Available to SMEs showed a positive relationship with economic growth while Interest rate and Inflation rate showed a negative and positive influence on economic growth respectively. Thus, we concluded that the independent variables play an important role in determining the impact of Small and Medium Scale Enterprises on economic growth in Nigeria. Based on this, it was recommended that the Nigerian Government should organize a national enterprise forum, which would focus on the contributions of SMEs in national development objectives; the Federal/State Ministries of Industry in collaboration with the National Association of SMEs should work out strategies for an annual report of SMEs operating in Nigeria and the Government should adopt policy measures to maintain a favorably low commercial banking lending rate as this will accelerate high investment in Small, Medium and large-scale businesses and subsequently in the long-run contribute significantly to economic growth
\end{abstract}

Keywords: small and medium scale enterprises, economic growth, gross domestic product, interest rate, inflation, national development

\section{Introduction}

The creation, growth, advancement as well as development of Small and Medium Scale Enterprises (SMEs) have provided evidence essential to the growth and development of many countries; particularly the developed and some developing nations like United States of America, China and India. In such countries, SMEs consist of over 98 per cent of the entire businesses and play a part in more than 65 per cent of employment opportunities (Deen, 2003). Globally, SMEs contribute over 50 per cent to the Gross Domestic Product (GDP) in developed countries. SMEs have remarkable effect on the economies of some European, American and Asian nations that successfully adopted and adapted it. In the U.S.A, SMEs formed over 50 per cent of the non-farm private GDP as well as generated 75 per cent new jobs in the economy. By the end of 2008, it was estimated that the US economy has an estimated population of 300 million, which was sustained by about 6 million businesses. Among these businesses, $27 \%$ employ less than 20 persons, $22 \%$ employ less than 50 persons while about $18 \%$ employ less than 100 persons (World Bank, 2001). In addition, SMEs also constitute 95 per cent of registered businesses in the world; particularly in the European Union, SMEs constituted 99.8 per cent of all businesses as well as employing around 76 million people which represents around 67.4 per cent of total employment in 2010 (Canetti, 2003). Consequently it became obvious that SMEs have been mainly recognized as the spine of the economy as well as play an important role to create employment opportunities, improve value of human resources, develop a 
philosophy of entrepreneurship, supports large scale industries as well as set-up new business opportunities (Boniface, 2006).

The advantages of SMEs to any country are definitely obvious. These include contribution to the economy in terms of: output of goods and services increment; generation of jobs at moderately low cost of capital, particularly in the rapid growing service sector; offer a medium for lessening disparities in income; develop a collection of skilled and semi-skilled workforce as a foundation for imminent industrial expansion (Iromaka 2006). Others include enhancing forward and backward linkages between economically, socially and geographically different segments of the economy; offer opportunities for enhancing and adapting suitable foreign and indigenous technical methods; provide an outstanding breeding ground for entrepreneurial and managerial ability, the significant shortage of which is frequently an immense restriction to economic growth and development. The question now is why has Nigeria SMEs not been able to attain to a substantial extent all or a few of the above listed advantages. This paper is guided by the following objectives: to ascertain if there is a significant association among the funding of SMEs and their contribution to Nigeria's economic growth and development; to appraise the influence as well as contributions of SMEs to Nigeria's economic growth and development; to find out factors other than funding hindering the growth and development of SMEs in Nigeria as well as suggest likely policy measures, programmes and incentives on the part of the Federal Government of Nigeria, entrepreneurs as well as the general public on the pressing need to support, advance, develop and maintain the growth of SMEs in Nigeria. These objectives if well articulated will assist in driving SMEs as a veritable means through which economic growth and industrialization can be facilitated and maintained in Nigeria.

According to a World Bank discussion paper in 2001, SMEs have gone through a great level of tests, difficulties, challenges, failures and subsequent collapse, because of inadequacy in infrastructures, whereas most of them are not capable to transform to large scale business enterprises which is the underlying principle behind the growth and development of SMEs (Transitional Industries). Regardless of the large number of SMEs all over the nation, their involvement in economic growth and development has not produced a major effect. This could be as a result of the difficulties they encounter. The difficulties confronting SMEs in many less developed nations are enormous. The most perturbing amongst these difficulties is provision of funds (Financial Availability). Most modern as well old-fashion SMEs mode of operations are not profitable prospects for deposit money banks (commercial banks), as they will like to reduce their risk portfolio. In Nigeria, the circumstance is not unusual, until in recent times in 2003, when the Banker's Committee got involved with a scheme titled the "Small and Medium Scale Industries Equity Investment Scheme (SMIEIS). The scheme was not successful and inevitably failed like majority of government credit schemes that were not properly planned, organized and implemented. The basis of this research is to significantly assess as well as deal with the poor, substandard, unacceptable and unsatisfactory performance of SMEs in Nigeria over the years (1970-2010) and to prove the fact that funding is a major restraint to SMEs contribution to economic growth and development in Nigeria.

\section{Review of Related Literature}

In acknowledging the vital role of industrialization in economic growth and development; an efficient strategy require robust, solid, concentrated and focused emphasis on growth and development of Small and Medium Scale Enterprises (SMEs). Therefore, SMEs is the means to an end of economic growth (Ako, 2001). Thus, the intention of developing, sustaining and supporting SMEs is to increase their involvement in economic growth in terms of increasing output of goods and services, and improving the lives of the populace. Nonetheless, the obvious philosophy and idea that effectively succeeded in most developed countries has not produced the much impact in the Nigerian economy. This may be as a result of inefficient, insignificant, unimportant and irrelevant roles assigned to this sub sector by Nigeria's macroeconomic policymakers. According to Gunu (2004), the growth, development and sustainability of SMEs, which is essential for the nation's socio-economic growth and development is a key problem facing the Nigerian economy today.

\subsection{Roles of SMEs in Nigeria's Economic Growth and Development}

One expected conclusion that has been drawn on SMEs irrespective of their level of economic activities in the real sub sector is that, if sufficiently financed and developed would bring about rural development as well as economic growth (Oyinlade, 2005). In Nigeria, as in most countries, these roles and functions would not be anticipated to be different noticeably, apart from dissimilarities in their scope as well as input for that matter. This results from the roles given to them (SMEs) by the nation's macroeconomic policymakers, economic planners, and the level to which they are prepared to perform these roles and functions.

An unbiased appraisal of the roles of SMEs around the world, though, suffers from insufficient information to 
precisely do justice to the role they perform in economic growth and development. Nevertheless, some insight on their contributions to economic growth can be gathered from inadequate analytical statistics, findings of previous studies to this effect and authorized journals, periodicals, magazines, newspapers etc. According to a CBN report in 1999, since the 1970s, the Less Developed Countries have shown increased interest in encouraging the growth and development of SMEs for three reasons

- The failure of previous industrial policies to create self-sustaining growth.

- The increased emphasis on self-reliant method to economic growth and development, which SMEs can promote.

- The greater concern to reduce the problems of rural-urban migration, and urban-rural investment disparity.

According to Ogun \& Anyanwu (1999), it is anticipated that the vigorous increment of SMEs would contribute considerably to wide range of growth and development objectives, which comprises of rural development, efficient utilization of local resources, creation of employment, development of domestic technology, mobilization of local funds for investment, human resource development, support as well as growth of the functions of local entrepreneurs and equitable distribution of income. It is a known fact that the organization of firms and industries in small and medium scale is a transition stage in a nation's phase of industrialization. That is, an intermediate phase between the prevalence of SMEs to large-scale industries. If this is the case, it must then follow that once a definite stage of industrial growth and development has been attained, the comparative significance of SMEs undertaking would reduce. Nonetheless, SMEs have continued to perform important functions even in the economies of highly industrialized countries and appear to continue doing so. A CBN report in 2006 indicated that development policies which are successful have emphasized the significance of SMEs in universal economic growth and development for the following reasons:

- To create considerable indigenous entrepreneurship

- To ease efficient mobilization of domestic resources such as domestic raw materials, capital, labour and technology.

- To decrease regional differences, brain drain, as well as rural-urban migration.

Most of all, it is contended that SMEs growth and development will steer great achievement of economic independence, growth and development with much emphasis in the development of rural areas (Inang \& Ukpong 1992). There is a universal conformity that the usual pattern of growth of many less developed countries in Africa have in previous years resulted in dualistic structure, as macroeconomic policy makers are likely to prefer the urban cities at the cost of the rural areas with resultant outcome of glaring regional differences in the level of income. Most SMEs are expected to be situated in the rural areas where their raw materials are found so that their effective support would act as a measure of industries decentralization, accelerating rural growth and development, steaming urban migration and the resulting difficulties of overcrowding in the cities among others. A study carried out by Izedomi (2011) on SMEs operations in Nigeria illustrates that greater part of SMEs are found in the commercial cities with service business enterprises and distribution businesses dominating. The prevalence of SMEs in a specific sector of the economy can be as a result of certain factors within that sector. These factors include:

- Minimum technology necessary for that enterprise;

- Low awareness of managerial knowledge and experience needed by the would be entrepreneur;

- Low capital resources needed for establishing such business venture (CBN, 2006).

\subsection{Financial Sector's Efforts towards Promoting SMEs}

The Financial sector in Nigeria is made up of all financial institutions in the economy. The Banker's Committee in Nigeria intervened on $19^{\text {th }}$ June 2001, with a scheme titled the Small and Medium Industries Equity Investment Scheme (SMIEIS). In their view, this was a response to the former president of Nigeria (Olusegun Obansanjo) concern as well as policy measures for the encouragement of small and medium industries as a medium for speedy process of industrialization, sustainable economic growth and development, reduction of poverty and creation of employment. The scheme required all banks operating in Nigeria to save $10 \%$ of their profit before tax (PBT) for equity investment in SMEs.

The scheme goals amongst other includes; helping in the setting up of new feasible SME projects thus accelerating economic growth, development of domestic technology, encourage indigenous entrepreneurship as well as create employment opportunities. The fund will be made accessible for projects in the real sector of the Nigerian economy, which includes agro-allied, information technology and telecommunication, manufacturing, 
educational establishment, services (directly associated to production in the real sector or to improve production), tourism and leisure, solid mineral, construction and any other activity as maybe determined from time to time by the Banker's Committee.

According to Adebayo (2003), to meet the criteria for the scheme, an enterprise, in addition to being involved in any of the activities listed above, must have a minimum asset base of N200million apart from land and working capital, with the number of staff working for the enterprise not less than 10 and not more than 300 . The enterprise have to be registered as a limited liability company with the Corporate Affairs Commission and act in accordance with all pertinent rules and regulations of the Companies and Allied Matters Act (1990) such as filing of annual reports as well as audited financial accounts. In addition, the enterprise has to act in accordance with all relevant tax laws and regulations and provide returns to the appropriate authorities. Timing of investment exit shall be a minimum of 3 years. Available data as at February 2003 revealed that about 80 banks have put aside N13.07 billion with 28 banks investing around N2.87 billion on 67 investments in 47 Small and Medium Enterprises (Sanusi, 2003).

Since 2006, more than N43 billion has been put into the scheme, with approximately 10 and 30\% investments (SMEDAN, 2006). In reality, the highest according to the committee is $30 \%$ a trend, which analysts say, goes against the aim for which the scheme was established and quenching the interest the scheme generated initially, when it was introduced. Though, many banks frequently assert to have contributed greatly to the growth and development of the SME sector, a glance into the record illustrates that the severe conditions set by them have made it tremendously difficult for SMEs operators to access funds from them (Inang \& Ukpong, 1992). Aside from Union Bank Plc, which has topped the list of 21 banks with payout of $65.54 \%$ of N3 billion set aside for SMEs in the previous financial year ended March 2005, First bank likewise has disbursed massive funds to SMEs. Most of the other banks have been unwillingly in contributing to the scheme, leading certainly to the future failure of the scheme. From a study carried out on SME operators in Nigeria in 2005, most SME operators are of the same opinion that the major restraint in operating a business in Nigeria is high cost of capital (Oni \& Daniya, 2012). In their view, accessing funds from banks for SME projects is like passing a camel through the eye of a needle, adding that, 'even the so called SMIEIS are just an idle fancy'. Analysts have accused the founding fathers of the project for failure to take into account the cultural nature and environment of the Nigerian society.

The Managing director and Chief Executive Officer of Spring Bank Plc, Mr. Mike Chukwu, said the main problem that has been recognized consisted of environmental, ethnic, cultural and social problems, because the SMIEIS not like most other SME financing arrangements is an equity fund. Adding that, 'what the bank is telling the entrepreneurs is: come let our bank join you in owning the company'. A lot of companies that are well established have cultural problems bothering on who owns it. Nigerians like to be the sole owners of their business. Nigerians need to adopt the philosophy of co-ownership. The issue ought to be tackled with continuous education programmes in order to inform the populace about the advantages of co-ownership.

Subsequent to the conclusion of the bank consolidation program, a number of banks' chief executives have through their statements been sending misleading signals to SME operators by frequently saying that the emergence of mega banks would not make giving out loans and advances easy, a sign that they do not entirely concur with the goals of SMIEIS. The Banker's Committee ought to look into this issue when they convene their next meeting of stakeholders.

\subsection{Problems Impeding the Development of SMEs in Nigeria}

SMEs are known worldwide to encounter some structural difficulties, problems or limitations, which if confronted can drive them to promote economic growth and development. Some of the principal problems SMEs face in Nigeria include the following:

\subsubsection{Inadequate Funding}

It is a known fact internationally that SMEs are funded by their owners' personal or family savings. Nonetheless, the high level of poverty and consequently low level of savings in Nigeria and other Less Developed Countries have made this source of funding for the establishment, growth and development of new and existing SMEs inactively low. This perhaps explains why most SMEs in Nigeria more often than not start off with inadequate funding and afterward start warming up for shut down if external funds from either the government or financial institution do not come.

According to Ezeh, 'the unpreparedness of small business owners in terms of capital prior to going into business is said to be accountable for their untimely failure' (Ezeh, 2002). Therefore, most SMEs in Nigeria are not 
adequately capitalized and as such are not capable to raise funds in the capital market owing to their inability to meet the stipulated strict conditions (i.e. registering as limited liability company) which is regarded as somewhat on the high side (Ireghan, 2009). Inadequate collateral is a key restraint for access to credit in SMEs from banks and other financial institutions. Other factors that hinders SMEs from accessing credits from banks and other established schemes like the SMIEIS, NEPAD, ACA, AGOA etc, include their incapability to raise the necessary equity contribution (a maximum of N500 million exclusive of land and working capital), which is very high. Others include scantily prepared project proposal as well as feasibility study of the project, incomplete and inaccurate financial records and lack of succession plan in event of the entrepreneur's exit (Aremu, 2010).

Funding is seen by this paper as the most hindering factor to the development and sustenance of SMEs towards contributing to Nigeria's economic growth in terms of output of goods and services.

\subsubsection{Inadequate Infrastructural Facilities}

The problem of unstable and unreliable supply of electricity, dilapidated roads, inadequate supply of water for both home and industrial use, inefficient and costly communication system, among others, have for long hindered the growth and development of SMEs in Nigeria. Nearly all SME operating in Nigeria have one or more power generating plants as an alternative source of power supply. The cost of obtaining, maintaining, sustaining and managing such generating plants are more often than not very expensive and this has made cost of production as well as prices of product very expensive, with the latter turning out to be more and more uncompetitive in comparison with the imported equivalent. It is estimated the cost of providing basic infrastructural amenities at $5 \%$ to $20 \%$ of the total cost of setting up a manufacturing and processing industry in Nigeria (Osoba, 2003). This cost will be significantly higher today taking into account the rapid rate of inflation in the economy.

\subsubsection{Low Capacity Utilization}

This is perpetually gotten from the low demand for SMEs products owing to their poor quality as well as exorbitant prices. Therefore, sales as well as profits have remained relatively low leading to poor returns on investment. A study of about 39 SME's performance in Nigeria illustrated that a majority of them operated at between 30\%-35\% of their established capacity between 1995-1996 with sales and profit volume showing little increase (NCI, 2001). Erratic supply of power as well as inadequate infrastructural amenities has contributed directly to low capacity utilization of the SMEs in the manufacturing sector in the country.

\subsubsection{Poor Planning and Management}

Management involves planning, coordination, organization and control of both human and natural resources in an organization to attain its set aims and objectives (Basil, 2005). Therefore, it involves getting things done appropriately and efficiently through people. Nonetheless, a survey of SMEs operating in LDCs showed that owners practically get everything done by themselves without seeking consultation from professionals or experts This has resulted to incompetence, inefficiency, wastage and under-utilization of resources available to the organization. In actual fact, planning is the essential function of management (Gold, 2005). Most SME operators venture into business on impulse without adequate feasibility study on the project or business (Mogano, 2001). The problem of poor planning and management in Nigeria's real sector has been traced to inadequate relevant and appropriate information or data relating to the proposed business ventures.

\subsubsection{Poor Education and Experience}

Closely associated to the problem of planning and management is the low level of education and inadequate business experience among SME operators in Nigeria (Alasan \& Yakubu, 2011). These have given an explanation for the lack of pioneering, inventive, innovative, dynamic, vibrant and entrepreneurial skills and abilities necessary to effectively confront and tackle issues as they emerge. Human resources therefore, constitute the foundation for wealth of nations (Cosson, 2003). According to him, "human resources make up the fundamental basis for the wealth of a nation". Capital and natural resources are inert factors of production, human beings are the active agents who accrue and amass capital, exploit natural and material resources, put up social, economic and political organization and carry forward national development. Without a doubt, a country which is incapable to build and develop the skills and knowledge of its citizens and utilizes them effectively in the economy will not be able to develop anything else. In the view of Essien \& Udofia (2006), effective and successful formal education is the only way to build as well as develop the human skills, expertise and competence required for the growth and development of SMEs in Nigeria and other LDCs.

\subsubsection{Raw Material Management and Choice of Appropriate Technology}

These are fundamental for growing and developing any business, be it large or small. The difficulty relating to 
small enterprises is the unavailability of quality and superior raw materials as well as its organization at the suitable price and time (Nigerian Economic Summit Group, 2002). In Nigeria, the majority of these raw materials are not produced in the country but imported. In addition, a general assessment made about domestic or locally made goods is the non existence of uniformity and standardization in them. Classification, categorization, cataloging as well as comparison is not feasible or impossible when the quality of the raw materials employed changes from article to article.

The SMEs in agro-allied industries encounter the peculiar difficulty of procurement, maintenance, conservation and storage of materials. Furthermore, the selection of suitable technical knowledge and expertise that would produce superior, quality and standard goods capable of challenging with their international equivalent, as well as meeting both domestic and foreign needs has to be appropriately addressed (Onyinlade, 2005). Most SMEs are confronted with the difficulty of marketing, advertising and selling. Their expansion relies by and large on the size and accessibility of markets for their output. The lack of ability to locate such multi outlets both in the local and international markets is a major setback. The cause for this consist of low standard and poor quality of their output, inadequate marketing skills and techniques resulting from high cost of advertising, promotion, branding, canvassing etc.

\subsubsection{Inadequate Conducive and Enabling Environment}

The Federal Government fiscal and monetary policies in Nigeria as it relates to business issues have been unpredictable, contradictory, inconsistent and from time to time conflicting (Adebayo, 2003). This has generated a lot of problems for domestic investors as against their foreign participants who have the alternative of making Nigeria a dumping ground for their output. Associated to this is the problem of unlawful taxes (business development tax, business registration tax, business premise tax, sanitation fees, signboard fees, stickers etc) most often than not by state and local government agencies (tax force on this or that). As a result of this, SMEs in Nigeria carry out their operations under high cost and unfavourable business environment.

\section{Method of Study}

In this section, the method used to carry out this study would be discussed. Emphases were laid on the research design, type of data employed, source of data, method of data collection, model specification, apriori expectation and estimation techniques.

\subsection{Research Design}

Baridam (1995) opined that a research design is described as "the structure or plan that is employed as a guide in gathering as well as analyzing data for a study". This study is a descriptive research and the method of the analysis includes the econometric techniques of ordinary least squares, co-integration and error correction model. It also made use of tabulations, and plain description. The econometric technique of ordinary least squares, co-integration and error correction model are used as the main measurement tools.

\subsection{Types of Data}

This study employed both primary and secondary data. The primary data consists of well structured questionnaires that are randomly distributed to 100 selected SME operators in agro-allied industries, manufacturing, distribution and services within Lagos metropolis for their respective responses. Lagos city is selected because of its industrial and commercial environment. Lagos accommodates a huge number of small and medium private businesses and therefore, provides a conducive environment for the growth of entrepreneurship. These features also make the city a relatively heterogeneous one. The population of our primary data includes all SMEs in Lagos metropolis that meets the following conditions:

- $\quad$ SMEs fully owned and managed by Nigerians and with headquarters located in Lagos;

- $\quad$ SMEs registered as limited liability companies and engaged the stated business above;

- SMEs that have been in operation for at least five years;

- $\quad$ SMEs that employ at least fifteen persons.

The secondary data consists of statistical records of the Central Bank of Nigeria (CBN) and the National Bureau of Statistics (NBS) for the period under review (1975-2012).

\subsection{Source of Data and Method of Data Collection}

The source of our primary data was mainly fieldwork. This means that we randomly distributed the 100 prepared questionnaires to SME operators in Lagos that met the conditions stipulated in 3.2 and the data (responded questionnaires) collected the same way. 
The secondary data was sourced from the Central Bank of Nigeria statistical bulletin and National Bureau of Statistics publications for the period under review (1975-2012). The method of data collection was by extracting time series figures from the publications of the above bodies.

\subsection{Model Specification}

The functional relationship between the dependent and the independent variables in our study are established as follows:

$$
G D P=f(F A S M E, I N T, I N F)
$$

Mathematically, the equation becomes:

$$
G D P=a_{0}+a_{1} \text { FASME }+a_{2} I N T+a_{3} I N F+U
$$

Specifying equation 2 in log form, the equation now becomes

$$
\log G D P=\log a_{0}+a_{1} \log \text { FASME }+a_{2} \log I N T+a_{3} \log I N F+U
$$

Where: GDP $=$ Gross Domestic Product;

FASME $=$ Finance Available to Small and Medium Scale Enterprises;

INT = Interest Rate;

$\mathrm{INF}=$ Inflation Rate;

$\mathrm{U}=$ Stochastic or error term.

\subsection{Apriori Expectation}

Based on economic theory, a rise in the finance available to SMEs will bring about an increase in their productive activities. Thus, a rise in their productive activities will therefore increase in the total output of goods and services produced in the country and lead to an increase in the GDP position of the country. Hence, the coefficient of FASME will be positive; i.e. $a_{1}>0$. Also, from economic theory, an increase in interest rate will discourage small and medium scale entrepreneurs from borrowing from banks and thus, reduce the level of productive activities in the country. Such reduction in the productive activities in the country will lead to fall in the GDP position in the country. Hence, the coefficient of INT will be negative; $a_{2}<0$. Finally, an increase in inflation rate (persistent rise in the general prices of goods and services) will encourage small and medium entrepreneurs to produce more and thus, increase the GDP position of the country. Hence, $a_{3}>0$.

\subsection{Estimation Techniques and Procedures}

The primary data collected were tested using percentage analysis and analyzed using both descriptive and inferential statistical techniques. While for the secondary data, the study employed ordinary least square, co-integration and error correction technique to estimate the model. Most economic time series data are non-stationary and as such there is need to analyze them to avoid spurious regression (Dickey and Fuller 1981). Consequently, these economic time series data were subjected to a unit root test to make them stationary. According to Maddala (2005), testing for unit root is a formalization of the Box-Jenkins approach of differencing the time series after a visual inspection of the correlogram. The analysis of and testing for Unit root naturally lead to the theory of co-integration; the theory of co-integration according to Granger (1969), addresses the issue of integrating short-run dynamics with long-run equilibrium. The theory demonstrates that if two or more variables are co-integrated, it implies that there is a meaningful long-run relationship between them; the Error Correction Model (ECM) can describe the short-run dynamics. The necessary condition for fitting an Error Correction Model is the existence of at least one co-integrating vector in the system.

\section{Data Presentation and Analysis of Data}

\subsection{Primary Data Estimation and Analysis}

The primary data instruments in our study were questionnaires and interviews used in gathering information from each of the owners of the selected firms. Eventually, data were gathered from eighty-four of the hundred initially selected from the sample size of the study. The data were analyzed using both descriptive and inferential statistical techniques.

\subsubsection{Factors Affecting the Growth of SMEs in Nigeria}

There are so many factors impeding the growth and development of SMEs in Nigeria. These factors have been summarized in five categories for evaluation by our sample entrepreneurs. These summarized factors are presented in table 1 . 
Table 1. Factors affecting the growth of SMEs in Nigeria

\begin{tabular}{lll}
\hline Factors & Number of Entrepreneurs & Percentage \\
\hline Inadequate Funding & 19 & 26 \\
Inexperience & 14 & 13 \\
Poor Marketing & 15 & 15 \\
Enabling Environment & 15 & 15 \\
All of the above & 21 & 31 \\
\hline
\end{tabular}

Table 1 shows that $26 \%$ of the sample entrepreneurs believes that funding is the major factor impeding SMEs growth, while $13 \%$ link it to inexperience on the part of entrepreneurs in business ventures. Poor marketing, Inadequate enabling environment were viewed by $30 \%$ as the major factor to SMEs growth. However, $31 \%$ of our sample entrepreneurs feel that all the factors affect the poor growth of SMEs in one way or the other. This implies that all the factors affect the growth of SMEs in Nigeria.

\subsubsection{Government Performance towards the Growth of SMEs}

The Nigerian government has initiated lots of programmes and incentives through its various policies for the growth and development of SMEs over the years. The opinion of our sample entrepreneurs (the beneficiaries) as regard to the performance of these government policies are presented below in Table 2 .

Table 2. Government performance towards the growth of SMEs

\begin{tabular}{lll}
\hline Rating & Number of Entrepreneurs & Percentage \\
\hline Above Average & 20 & 13 \\
Average & 25 & 26 \\
Below Average & 39 & 61 \\
\hline
\end{tabular}

As shown in Table 2, majority (61\%) of the sample entrepreneurs feel the government has not done much in developing and sustaining the growth of SMEs, while $26 \%$ rated government performance as average. Only $13 \%$ feel that the government has performed above average. This implies that the government has fared well, but still needs to do more to develop this sub-sector.

\subsubsection{Financial Institutions Performance towards the Development of SMEs}

Financial institutions are considered in any economy as the engine room for growth and development in terms of mobilizing funds for investment. The sample entrepreneurs pour out their feelings regarding Financial Institutions performance in promoting the growth of SMEs. Their ratings are presented in Table 3.

Table 3. Financial Institutions performance towards the development of SMEs

\begin{tabular}{lll}
\hline Rating & Number of Entrepreneurs & Percentage \\
\hline Above Average & 24 & 23 \\
Average & 29 & 36 \\
Below Average & 31 & 41 \\
\hline
\end{tabular}

The above Table 3 shows that $23 \%$ of our sample entrepreneurs feel that financial institutions have performed above average in promoting the growth of SMEs in terms of funding, while $36 \%$ feel that financial institutions performance is on the average. Finally, $41 \%$ of the sample entrepreneurs are of the opinion that financial institutions have performed below average regarding the promotion and growth of SMEs through funding. The implication of this result is that financial institutions have not done much in developing SMEs in terms of financing this subsector.

\subsubsection{Consumers Performance towards the Growth of SMEs in Nigeria}

Consumers are the end users of goods and services, and thus, determine output (supply). As demand increases, supply also increases all things being equal. Our sample entrepreneurs rating of consumers' performance towards the growth of SMEs in terms of patronage are presented below in table 4. 
Table 4. Consumers performance towards the growth of SMEs in Nigeria

\begin{tabular}{lll}
\hline Rating & Number of Entrepreneurs & Percentage \\
\hline Above Average & 3 & 8 \\
Average & 7 & 18 \\
Below Average & 29 & 74 \\
\hline
\end{tabular}

The above Table 4 shows that majority (74\%) of our sample entrepreneurs feel that consumers have not performed much (below average) as regarding patronizing local made goods thereby discouraging their increased output. While $18 \%$ of the entrepreneurs, feel that consumers have performed on the average. Only $8 \%$ of the sample entrepreneurs indicated that consumers have performed above average. This implies that consumers have not been a source of encouragement to SMEs in terms of patronizing their products.

\subsubsection{Reasons for Low Output of SMEs Products}

We ought to know the factors responsible for the low output of SMEs products towards contributing to GDP in terms of output of goods and services. Some major reasons are presented in Table 5.

Table 5. Reasons for low output of SMEs products

\begin{tabular}{lll}
\hline Rating & Number of Entrepreneurs & Percentage \\
\hline Low patronage of the Product & 12 & 31 \\
Low quality of the product & 3 & 8 \\
Poor publicity of the product & 5 & 12 \\
All of the above & 19 & 49 \\
\hline
\end{tabular}

From Table 5, it shows that $31 \%$ of our sample entrepreneurs feel that low patronage is the reason for the low output of SME products. About $8 \%$ link it to low quality of SME products, while $15 \%$ attribute it to low publicity of the products. Majority of the entrepreneurs (49\%) feel that all the factors listed above contribute to the low output of SME products. This implies that all the factors identified above contribute the low output of SME products.

\subsubsection{Effective Policy Measures and Incentives to Address These Problems}

Policies are formulated either encourage or discourage expedient conduct or action. This sub-section sought to determine whether the Supply-Driven approach, the Demand-Driven approach, or both approaches are suitable to address this poor performance of SMEs. The responses of our sample entrepreneurs are presented in Table 6 .

Table 6. Effective policy measures to address these problems

\begin{tabular}{lll}
\hline Rating & Number of Entrepreneurs & Percentage \\
\hline Supply-Driven Approach & 9 & 23 \\
Demand-Driven Approach & 9 & 23 \\
Both Approaches & 21 & 54 \\
\hline
\end{tabular}

Table 6 shows that $54 \%$ of our sample entrepreneurs feel that both approaches will effectively promote the growth of SMEs towards contributing to GDP in terms of output of goods and services. The rest of the sample entrepreneurs feel that either of the approaches will promote SME growth. This implies that both approaches will effectively boost SME growth in Nigeria.

\subsection{Discussion of Findings}

The first factor examined in this research was the factor affecting the growth of SMEs in Nigeria. The research showed that all the factors stated in table 1 affect the growth and development of SMEs in Nigeria.

The second issue addressed is government performance towards developing SMEs in Nigeria; the research showed that most of the sample entrepreneurs were of the opinion that most of the government policies towards the development of SMEs have not yielded much and this can be attributed to poor implementation of policies and corrupt practices of government officials.

On the issue of financial institutions performance towards the development and sustenance of SMEs in Nigeria, 
the research found out that $59 \%$ of the sample entrepreneurs indicated that financial institutions have actually done much in terms of financing investment in small or medium scale. While $41 \%$, indicated that financial institutions have not performed much in promoting the growth and development of SMEs. This is because of their various unfavourable conditions for granting loans for investments in this sub sector.

Another issue is consumers' performance towards the growth of SMEs. The result showed that $26 \%$ of the sample entrepreneurs indicated that consumers have performed well through patronage of locally made goods, thereby boosting their increase output. Whereas $74 \%$ indicated that consumers have not boosted SMEs output by patronizing their various products. Reasons for low output of SMEs products was studied, and the result indicated that low patronage resulting from high competition from foreign counterparts, low quality and poor publicity of the products contribute significantly to the low output from this sub sector. About $51 \%$ attribute this low output to either of these factors stated above, while $41 \%$ indicated that all the factors are responsible for the low output of SMEs.

The last issue is the best policy approach to address the poor performance of this sub sector. While about $46 \%$ indicated either the Supply-Driven or the Demand-Driven approach to promote the growth and development of SMEs in Nigeria, $54 \%$ agreed that effective adoption of both approaches would definitely boost the growth of this sub sector.

\subsection{Secondary Data Analysis}

This section seeks to examine the empirical magnitude of Finance Available to Small and Medium Enterprises, Interest rate and Inflation on the growth and development of SMEs towards contributing to GDP in terms of output of goods and services.

Table 7. Ordinary Least Square (OLS) regression result

\begin{tabular}{lllll}
\hline Dependent Variable: GDP & & & \\
\hline Variable & Coefficient & Std Error & t-statistic & Prob \\
\hline C & -145502.8 & 1406301 & -0.103465 & 0.9183 \\
FASME & -0.020430 & 0.016599 & -1.230845 & 0.2286 \\
INT & 233928.8 & 82098.58 & 2.849365 & 0.0081 \\
INF & -55890.48 & 32144.56 & -1.738723 & 0.0931 \\
$\mathrm{R}^{2}$ & 0.250179 & & Mean dependent var & 2250544 \\
Adjusted R & 0.169841 & & S.D. dependent var & 3253978 \\
S.E. of regression & 2964799 & & Akaike info criterion & 32.75899 \\
Sum squared resid & $2.46 \mathrm{E}+14$ & & Sxhwarz criterion & 32.94220 \\
Log likelihood & -520.1438 & & F-statistic & 3.114078 \\
Durbin-Watson stat & 0.822638 & & Prob(F-statistic) & 0.042051 \\
\hline
\end{tabular}

In the short-run model above, the $\mathrm{R}^{2}$ (Coefficient of determination) indicates that $25 \%$ of the variations in Gross Domestic Product is explained by Financial Availability to SMEs, Interest rate and Inflation rate. This is not a good fit since the explanatory variables did not explain about $75 \%$ variation in Gross Domestic Product. Furthermore, the D.W. statistics is less than 2, indicating the presence of autocorrelation. In order to avoid spurious regression as shown in the short-run model above, both unit root test and co-integration test will be conducted. In testing for the unit root of the variables, the Augmented Dickey Fuller test was employed to determine the degree of integration of the variables. That is how many times a variable should be differenced to attain stationarity (Dickey \& Fuller, 1981). The co-integration and error correction model are used to determine if there is any long run relationship between the variables in the model. The unit root test result is shown below.

Table 8. Unit root test

\begin{tabular}{lll}
\hline Variable & ADF & Order of Integration \\
\hline GDP & -4.454703 & I (1) \\
FASME & 3.256796 & I (1) \\
INT & -5.775924 & I (1) \\
INF & -5.258029 & I $(1)$ \\
\hline
\end{tabular}

Note. $5 \%$ ADF Critical value for the test is -2.9665 . 
Running ADF tests for change in variables in table 8 above shows that at $5 \%$ level of significance, all the variables were to be integrated of the order 1.That is the calculated ADF results for all the variables are greater than the ADF critical value. This result from the unit root test therefore enables us to check if there is any long-term relationship between the variables. In order to check this long-run relationship between the variables, the Johansen co-integration technique was used in this study. Non-stationary time series can be co-integrated if there is a linear combination of them.

Table 9. Johansen Co-integration test result

\begin{tabular}{lllll}
\hline Eigenvalue & Likelihood Ratio & $5 \%$ Critical Value & $1 \%$ Critical Value & Hypothesized No of CE(s) \\
\hline 0.904181 & 155.1361 & 47.21 & 54.46 & None $^{* *}$ \\
0.852940 & 89.46789 & 29.68 & 35.65 & At most $1^{* *}$ \\
0.617964 & 35.79433 & 15.41 & 20.04 & At most $2^{* *}$ \\
0.271034 & 8.851578 & 3.76 & 6.65 & At most $3^{* *}$ \\
\hline
\end{tabular}

Note. ${ }^{* * *}$ ) denotes rejection of the hypothesis at $5 \%(1 \%)$ significance level;

L.R test indicates 4 cointegrating equation(s) at 5\% significance level.

From our co-integration result, we had at least four co-integrating equations which satisfy the condition for carrying out an error correction model analysis. The critical aspect of this study is the analysis of a long-run relationship on the impact of Financial Availability to Small and Medium Scale Enterprises, Interest rate and Inflation rate on the growth and development of SMEs (in terms of finance) towards contributing to economic growth measured by Gross Domestic Product (GDP). Therefore, adopting the general-to-specific approach, a Parsimonious Error Correction Model is obtained as shown below in table 10.

Table 10. The parsimonious error correction model

\begin{tabular}{|c|c|c|c|c|}
\hline \multicolumn{5}{|c|}{ Dependent variable $\Delta$ (GDP) } \\
\hline Variable & Coefficient & Std. Error & t-statistic & Prob. \\
\hline $\mathrm{C}$ & 124007.4 & 146512.1 & 0.846397 & 0.4126 \\
\hline$\Delta(\mathrm{GDP}(-1))$ & 0.575243 & 0.182807 & 3.146727 & 0.0077 \\
\hline$\Delta(\mathrm{GDP}(-2))$ & -0.628477 & 0.165299 & -3.802073 & 0.0022 \\
\hline$\Delta(\mathrm{GDP}(-3))$ & 0.601124 & 0.155581 & 3.863747 & 0.0020 \\
\hline$\Delta(\mathrm{GDP}(-4))$ & 0.738697 & 0.208977 & 3.534821 & 0.0037 \\
\hline$\Delta($ FASME $)$ & -0.484808 & 0.075377 & -6.431750 & 0.0000 \\
\hline$\Delta(\operatorname{FASME}(-1))$ & 6.077205 & 0.835854 & 7.270652 & 0.0000 \\
\hline$\Delta($ FASME $(-2))$ & 6.780534 & 3.207361 & 3.114054 & 0.0544 \\
\hline$\Delta($ FASME $(-3))$ & -25.92209 & 5.388269 & -4.810838 & 0.0003 \\
\hline$\Delta(\mathrm{INT})$ & 24382.04 & 18264.85 & 1.334916 & 0.2048 \\
\hline$\Delta(\mathrm{INT}(-2))$ & -26587.70 & 14326.58 & 4.855830 & 0.0863 \\
\hline$\Delta(\mathrm{INF})$ & 5501.822 & 4104.800 & 1.340339 & 0.2031 \\
\hline$\Delta(\operatorname{INF}(-2))$ & 10831.22 & 4644.212 & 3.332198 & 0.0364 \\
\hline $\operatorname{ECM}(-1)$ & -0.024461 & 0.057307 & 0.426841 & 0.6765 \\
\hline R-squared & 0.802007 & Mean dependent var & 28055.98 & \\
\hline Adjusted R-squared & 0.884014 & S.D dependent var & 2281373 & \\
\hline S.E. of regression & 288442.7 & Akaike info criterion & 28.28853 & \\
\hline Sum squared resid & $1.08 \mathrm{E}+12$ & Schwarz criterion & 28.96045 & \\
\hline Log likelihood & -367.8952 & F-statistic & 124.1133 & \\
\hline Durbin-Watson stat & 2.240277 & Prob(F-statistic) & 0.000000 & \\
\hline
\end{tabular}

From the Parsimonious Error Correction Model above, the coefficient of determination was significantly high, that is, the explanatory variables included in the model explained $80 \%$ of the total variation in economic growth measured by Gross Domestic Product (GDP). The remaining 20\% variation is explained by other variables not included in the model. This shows that the model is a good fit. In addition, the overall regression model was significant as shown from the value of the F-statistic which is 124.11. The Durbin-Watson statistic of 2.24 shows that there is minimal autocorrelation. The result of the Alkaike and Schwarz criterion reveals that the model is 
good due to the low difference in values between both of them. The Error Correction Model is rightly signed, relatively low and it is not statistically significant. Some of the coefficients of the explanatory variables appeared with their expected signs while some do not. For example, lag 1 and lag 2 values of Financial Availability to SMEs came out with their expected signs and they are statistically significant at $5 \%$. The current lending rate appears to be insignificant at 5\% level and it does not appear with the expected sign. While the coefficient of lag 2 value of lending rate came out with the expected sign and it is statistically significant at $5 \%$ level. Both the current and lag 2 value of inflation came out with the appropriate sign, but it is only the lag 2 value of inflation that is statistically significant at $5 \%$.

\section{Conclusion and Recommendations}

The research examined the effect of finance on Small and Medium Scale Enterprises on Nigeria's economic growth. It was discovered that after co-integrating the explanatory variables of Financial Availability to Small and Medium Scale Enterprises (FASME), Interest Rate (INT) and Inflation Rate (INF) on Gross Domestic Product (GDP) that there exists a long-run relationship among the variables in the model and the overall regression model was statistically significant at $5 \%$. This shows that the variables included in our model contributed to economic growth in Nigeria during the period of this study. From our results, it was discovered that our findings supported the claims of Dozie (1999) that finance is a major catalysts to SMEs growth and development which contributes in improving economic growth of the Nigerian economy. It is based on this that the following recommendations were made; the Nigerian Government should organize a national enterprise forum, which would focus on the contributions of SMEs in national development objectives; the Federal/State Ministries of Industry in collaboration with the National Association of SMEs should work out strategies for an annual report of SMEs operating in Nigeria; the Government should adopt policy measures to maintain a favorably low commercial banking lending rate as this will accelerate high investment in Small, Medium and large-scale businesses and subsequently in the long-run contribute significantly to economic growth; the Government should set-up a Small and Medium Industrial Development Bank (SMIDB) to finance SME ventures in manufacturing, information technology etc; and most significantly, the government should adopt both demand-driven as well as supply driven approaches to SMEs growth and development towards contributing to economic growth in the long-run.

\section{References}

Adebayo, J. Y. (2003). Manufacturing Enterprises in Nigeria, Is Finance a constraint to Performance? Journal of Economic Reform, 1(3).

Ako, R. M. (2001). Managing Small and Medium Scale Enterprises for Sustainable Industrial Development: A Policy Framework for Nigeria. The Nigerian Economics Society, 99-111.

Alasan, S. L., \& Yakubu, A. L. (2011). An Empirical Study of Small Scale Financing in Nigeria. Journal of Unilorin Business School, 1(1), 87-96.

Aremu, M. A. (2010). Small and Medium Scale Enterprises As A Means of Employment Generation and Capacity Building in Nigeria. A Paper Presented at the International Conference on Management and Enterprise Development on "Intellectuals and New Strategies for Sustainability Development of the Third World" Held at Conference Center, University of Ibadan, Ibadan, Nigeria, October 5th - 8th.

Baridam, D. M. (1995). Research Methods in Administrative Sciences. Port Harcourt, Nigeria: Belk Publishers.

Basil, A. N. O. (2005). Small and Medium Enterprises (SMES) in Nigeria: Problems and Prospects. Ph.D. Thesis, St. Clements University.

Boniface, C. U. (2006). Small and Medium Industries Equity Investment Scheme (SMIEIS) headache for banks. Business Times Magazine, 37(36), 35.

Canetti, E. (2003). Innovation, Specialization and E - Finance for Small and Medium Enterprises. Cache Magazine, Kaduna, Nigeria.

Central Bank of Nigeria (1986). Survey of Business Establishments in Nigeria (1981-1985). Lagoss.

Central Bank of Nigeria (1999). Economic and Financial Review, 35(3).

Central Bank of Nigeria (2005). Annual Reports of Accounts. Various Issues: Lagos.

Central Bank of Nigeria (2010). Statistical Bulletin.

Central Bank of Nigeria. (2006). Annual Report. Abuja.

Cookey, A. E. (2008). Economics and the Challenges of Expanding Scope and Methodology. Nigeria. 
Cosson, M. (2003). The Entrepreneur: An Economic Theory (2nd ed.). Edward Elgar Publishers. http://dx.doi.org/10.4337/9781843765639

Deen, M. H. (2003). Stake-holders Role and the Development Benefits in a virile SME sector. A Lecture paper delivered at the Manufacturing Association of Nigeria.

Dickey, A. D., \& Fuller, W. A. (1981). Distribution of the Estimators for Autoregressive Time Series with a Unit Root. Journal of American Statistical Association, 74.

Dozie, P. (1999). The Role of Small and Medium Scale Industries in the Nigerian Economy. A Lecture paper submitted to the Nigerian Economic Summit.

Essien, P., \& Udofia, A. (2006). Evolving a National Framework for the Emergence of a Strong and Virile Small and Medium Scale Industry Sub-Sector in Nigeria. A Seminar Paper Presented at MAN House.

Ezeh, J. A., \& Onodugo, V. A. (2002). Business Policy and Strategic Management: Issues and Trends. Enugu: Kinsmann Publisher Ltd.

Gold, S. K. (2005). Entrepreneur's Notebook. Learning Ventures Press.

Gunu, U. (2004). Small Scale Enterprises in Nigeria: Their Start Up, Characteristics, Sources of Finance and Importance. Ilorin Journal of Business and Social Sciences, 9(1\&2), 6-43.

Inang, E., \& Ukpong, G. (1992). A Review of Small Scale Enterprises Credit Delivery Strategy in Nigeria. CBN Economic and Financial Review, 30(4).

Ireghan, C. (2009). Small Scale Business Development in Nigeria. In Ireghan, C. (Ed.), The Place of Small and Medium Scale Business in the development of a nation State. Nigeria: Lagos, Kaycee Publishers.

Iromaka, C. (2006). Entrepreneurship in small business firms. Ikeja: G-Mag. Investments Ltd, (Educational Publishers), 49-56.

Izedomi, A. (2011). Principles of Management. Nigeria: Benin, Alfred-Joe Publishers.

Lemo, T. (2003). Financing Small and Medium Scale Industries in Nigeria: Issues and Options. The Guardian.

Maddala, G. S. (2005). Introduction to Econometrics. Wiley Students' Edition.

Mogano, M. (2001). How to Start and run your own business. Graham and Trotman.

NCI. (2001). The thirteenth meeting of the national council on industry.

Nigerian Economic Summit Group. (2002). A Survey of Micro and Small Enterprises. NESG Digest, Lagos.

Ogun, O., \& Anyanwu, J. C. (1999). Financing Small and Medium Scale Enterprises in Nigeria: Lessons from International Experience. Nigerian Financial Review, 8(1).

Oni, E. O., \& Daniya, A. A. (2012). Creation of Small and Medium Scale Enterprises in Nigeria: The Entrepreneurial Perspective. International Journal of Management and Administrative Sciences, 1(4).

Osoba, A. M. (2003). Towards the Development of Small Scale Industries in Nigeria. Nigerian Institute of Social and Economic Research

Oyinlade, A. O. (2005). Effective Financing of Small/Medium Scale Enterprises as an impetus for poverty alleviation in Nigeria: An analytical approach. International Journal of Economics and Development Issues, 51.

Sanusi, J. O. (2003). Overview of Government's Effort in the Development of SMEs and the emergence of Small and Medium Industries Equity Investment Scheme (SMIEIS). A workshop paper presented at the National Summit on SMEIS organized by the Banker's Committee in Lagos.

World Bank. (1989). The Role of Small and Medium Scale Industries in Less Developing Countries. World Bank Technical Paper, No. 25. World Bank, Washington D. C.

World Bank. (1995). A Diagnostic Review of Small and Medium Scale Industries in Nigeria. World Bank Interim Report, No. 101. World Bank, Washington D. C.

World Bank. (2000). Small Firm Dynamism in East Asia. A Paper on Indonesia Small Businesses. World Bank Institute, World Bank, Washington D. C.

World Bank. (2001). Regional Program on Entrepreneurial Development. World Bank Discussion Paper, No. 53. World Bank, Washington D. C. 


\section{Copyrights}

Copyright for this article is retained by the author(s), with first publication rights granted to the journal.

This is an open-access article distributed under the terms and conditions of the Creative Commons Attribution license (http://creativecommons.org/licenses/by/3.0/). 